\title{
TOWARDS SYNERGY BETWEEN TOURISM AND NATURE CONSERVATION. THE CHALLENGE FOR THE RURAL REGIONS: THE CASE OF DRAWSKIE LAKE DISTRICT, POLAND
}

\author{
Joanna Adamowicz ${ }^{1}$
}

Received 30 September 2010; Accepted 15 October 2010

\begin{abstract}
Sustainable tourism is seen as one of the ways to improve the socio-economic situation in lagging behind rural areas while maintaining high natural values and attractiveness. Whether and how it could be done was studied in the Drawskie Lake District in North-western Poland via document analysis and expert interviews. The biggest impediments are: inconsistent legal framework, incompatible infrastructure for increased number of tourists where there are no long-term strategies for development because of the instability of local authorities which hampers the co-operation of tourism management, nature conservation and municipalities as the responsibilities are not clearly agreed. Yet, local initiatives have found innovative ways to combine tourism, nature conservation and generate income.
\end{abstract}

Keywords: Sustainable tourism, ecotourism, nature conservation, local co-operation, Poland

Streszczenie: Synergia pomiędzy turystyką i ochroną przyrody. wyzwanie dla terenów wiejskich na przykładzie pojezierza drawskiego w Polsce. W rozwoju turystki zrównoważonej upatruje się szansę na poprawę sytuacji społeczno-gospodarczej w regionach o charakterze wiejskim, które dysponuja dużym potencjałem przyrodniczym i sa atrakcyjne dla turystyki. Na przykładzie Pojezierza Drawskiego badano czy i w jaki sposób realizacja tego kierunku rozwoju byłaby możliwa. Materiał badań stanowiły wyniki przeprowadzonych wywiadów eksperckich i analizy dokumentów. Za największe przeszkody w rozwoju turystyki zrównoważonej uznano: niespójne ramy prawne, niewystarczający rozwój infrastruktury turystycznej wobec wzrastającej liczby turystów, który jest z kolei wynikiem braku długofalowej strategii rozwoju turystki. Opracowanie takiej strategii oraz jej konsekwentne wdrażanie nie jest możliwe ze względu na ciagłe zmiany polityczne na szczeblu władz lokalnych. Współpraca między sektorem turystycznym i ochroną przyrody oraz lokalnymi władzami jest utrudniona także ze względu na brak ustalonego podziału zadań i odpowiedzialności w zakresie turystyki w regionie. Jednak w ramach lokalnych

\footnotetext{
${ }^{1}$ Joanna Adamowicz, research assistant, Department of Resource Management, University of Applied Sciences and Arts Hildesheim/Holzminden/Göttingen, Büsgenweg 1a, 37077 Göttingen, Germany; and Institute of Forest Policy, Forest History and Nature Conservation, Georg-August-Universität Göttingen; from 2009 senior expert in General Directorate for Environmental Protection in Poland
} 
inicjatyw znaleziono innowacyjne rozwiązania, które łączą turystykę i ochronę przyrody oraz generują nowe źródła dochodu.

Słowa kluczowe: turystyka zrównoważona, ekoturystyka, ochrona przyrody, współpraca lokalna, Polska

\section{Introduction}

In 1989 Poland entered a period of social, political and economic transformation. Due to its large agricultural sector with rural regions accounting for over $60 \%$ of the overall $312,677 \mathrm{~km}^{2}$ and for $38 \%$ of the population ${ }^{2}$ (GUS 1995) Poland has been the hardest hit by the negative trends associated with the structural changes of the transition period. A decrease in the export of agricultural products to the former communist countries and the simultaneous inflow of subsidised food products from the European Union (EU) countries resulted in the breakdown of the agricultural market and a decrease in agricultural production profitability and hence a sharp decline in the standard of living in rural areas. The collapse of the state farms, especially in the northern, western and south-western parts of the country, where they accounted for more than $40 \%$ of the farms, caused a very high level of unemployment (approximately $25-30 \%$ ) in these areas (Frenkel 1997). There have been major changes concerning the question of land ownership connected with the collapse of the state farms and a major transfer of land resources into private hands via the intermediation of the Treasury Agricultural Property Agency (Bański 2002).

In this respect, in the 1990 s and the early $21^{\text {st }}$ century the Polish rural development policy has been dominated by the attempt to solve social problems, in particular by the implementation of regulations improving the profitability of agriculture and supporting employment in nonagricultural fields of production and service. In 1994, the government of Poland issued two documents: The Assumptions of the Social and Economic Policy for Rural Areas, Agriculture and Food Economy until the Year 2000 and The Assumptions of the Development of a Tourist Economy. In both of these documents, much attention has been paid to the promotion of tourism development in the rural areas characterised by low efficiency agriculture (mainly in the eastern regions of Poland) and by high unemployment (northern and western voivodships) as an additional source of income for the farmers and also a factor that might prevent the social and general decline of rural areas. The Polish sustainable development policy promotes alternative forms of tourism, the development of which is much desired in rural areas (Kowalczyk 1996).

The importance of tourism for the economy is also stressed in EU policies and is reflected in support systems. As balanced development is crucial for the general regional policy of the EU, the largest share of funding is reserved for the least developed areas (European Commission 1999). The renewed EU tourism policy of 2005 also stresses the role of sustainable tourism development in preserving the strength of the natural potential and cultural heritage, providing new jobs in the service industry and the crafts sector ${ }^{3}$. The World Tourism Organisation ${ }^{4}$ declared that sustainable tourism is "envisaged as leading to management of all resources in such a way that economic, social and aesthetic needs can be fulfilled while maintaining cultural integrity, essential ecological processes and biological diversity and life support systems".

As experience in many regions of Europe and the world shows, tourism is a double-edged sword having both a negative and a positive economic, social and environmental impact. Tourism needs to be managed and controlled especially carefully in ecologically sensitive areas of high natural value. The relation between tourism and protected areas has a long history.

\footnotetext{
2 Rocznik statystyczny. Warszawa: Glówny urzad statystyczny

3 European Commission (1999). Council regulation (EC) No 1260/1999 of 21 June 1999. Official Journal of the European Communities http://ec.europa.eu/employment_social/esf2000/regulations/sf/en.pdf - 5.12.2006.

4 WTO - UNEP Concept paper - International Year of Ecotourism 2002 http://www.worldtourism.org/sustainable/IYE/WTO-UNEP-Concept-Paper.htm -10.04.2007.
} 
Budowski (1976) argued that there could be a symbiosis where tourism is based on values derived from nature and its resources; it could provide an economic value for the conservation of habitats and species. The best known ways for nature conservation to benefit profit from tourism are protected area admission fees, payment for guided tours, raising the awareness of the importance of conservation by improving the ecological literacy of the local inhabitants and the tourists and creating alternative sources of income for the local community (Budowski 1976, Eagels et al. 2002, Goodwin 1996, Ross and Wall 1999). Burger (2000) gives examples of the interface between humans and ecosystem integrity on the landscape scale and assumes that tourism can theoretically play a major role in preserving biodiversity.

However, the positive role of tourism in nature conservation has been demonstrated in theory but rarely verified in practice (Jagusiewicz 2000, Poskrobko 2005, Ross and Wall 1999, Zaręba 2006). The relationship is discussed in protected areas with regard to the occurring conflicts, which result from excessive pressure exerted by the growing number of tourists (BaranowskaJanota 1995, Kistowski 2004, Matuszewska 2003). Not all forms of tourism support conservation. The authors postulate the implementation of ecotourism in order to prevent the negative impacts. Goodwin (1996) defined ecotourism as "low-impact nature tourism", which supports the maintenance of species and habitats either directly through a contribution to conservation and/or indirectly by providing revenue to the local community sufficient for local people to value, and therefore protect, their wildlife heritage area as a source of income".

With respect to the environmental conditions and biodiversity, rural regions in Eastern and North-western Poland are among the best in Europe ${ }^{6}$ and are often protected (this holds for more than $30 \%$ of the country, GUS $2005^{7}$. Nowaczek and Fennell (2002) questioned Polish tourists to determine the potential that ecotourism in Poland may have. These authors underline the lack of national and local empirical research studies on ecotourism and the relation between tourism and nature conservation in Poland.

This paper provides an empirical contribution to the issue mentioned above, taking the Drawskie Lake District as a case study. This District is one of the less developed Polish rural regions of high natural value and recognised as a tourist attraction. By analysing the negative and positive impacts of tourism, this study investigates whether co-operation between the tourism industry and nature conservation could contribute to preserving a rural landscape with its biodiversity and support the regional development of this area. The results collected from studying official planning documents and expert interviews are discussed in the context of changes in rural regions resulting from the transformation process.

\section{The Drawskie Lake District - case study area}

The Drawskie Lake District is a geographical region of approximately $4000 \mathrm{~km}^{2}$, located in North-western Poland, in the voivodship of Westpomerania. Its extent and borders are defined differently by different authors (Łęcki \& Maluśkiewicz 1972, Kondracki 1998, Borówka 2004). Seven rural municipalities Drawsko Pomorskie, Złocieniec, Czaplinek, Ostrowice, Borne Sulinowo, Barwice, Połczyn Zdrój that are part of or in the neighbourhood of the Drawski Landscape Park and belong to the region were selected as a case study (figure 1).

As a typical rural area it is characterised by a very low population density of around 35 persons $/ \mathrm{km}^{2}$. The area is used for agricultural and forestry purposes. Over $40 \%$ of it is covered by forest. The loss in economic importance of the sector of agriculture, the collapse of the former state farms and economic restructuring have resulted in an unemployment rate as high as around $30 \%$. The employment structure includes agriculture, forestry and fishery (23\%), industry $(31 \%)$, and service $(46 \%)$.

\footnotetext{
${ }^{5}$ Nature tourism is a form of tourism which based on natural potentials and therefore places its offer in areas of high natural attractiveness, often in remote and unique scenic areas.

${ }^{6}$ National Development Plan: Poland 2004-2006. Council of Ministries:

http://www.funduszestrukturalne.gov.pl/English/National+Development+Plan/National+Development+Plan.htm 8.04.2006.

${ }^{7}$ Rocznik statystyczny. Warszawa: Glówny urzad statystyczny
} 


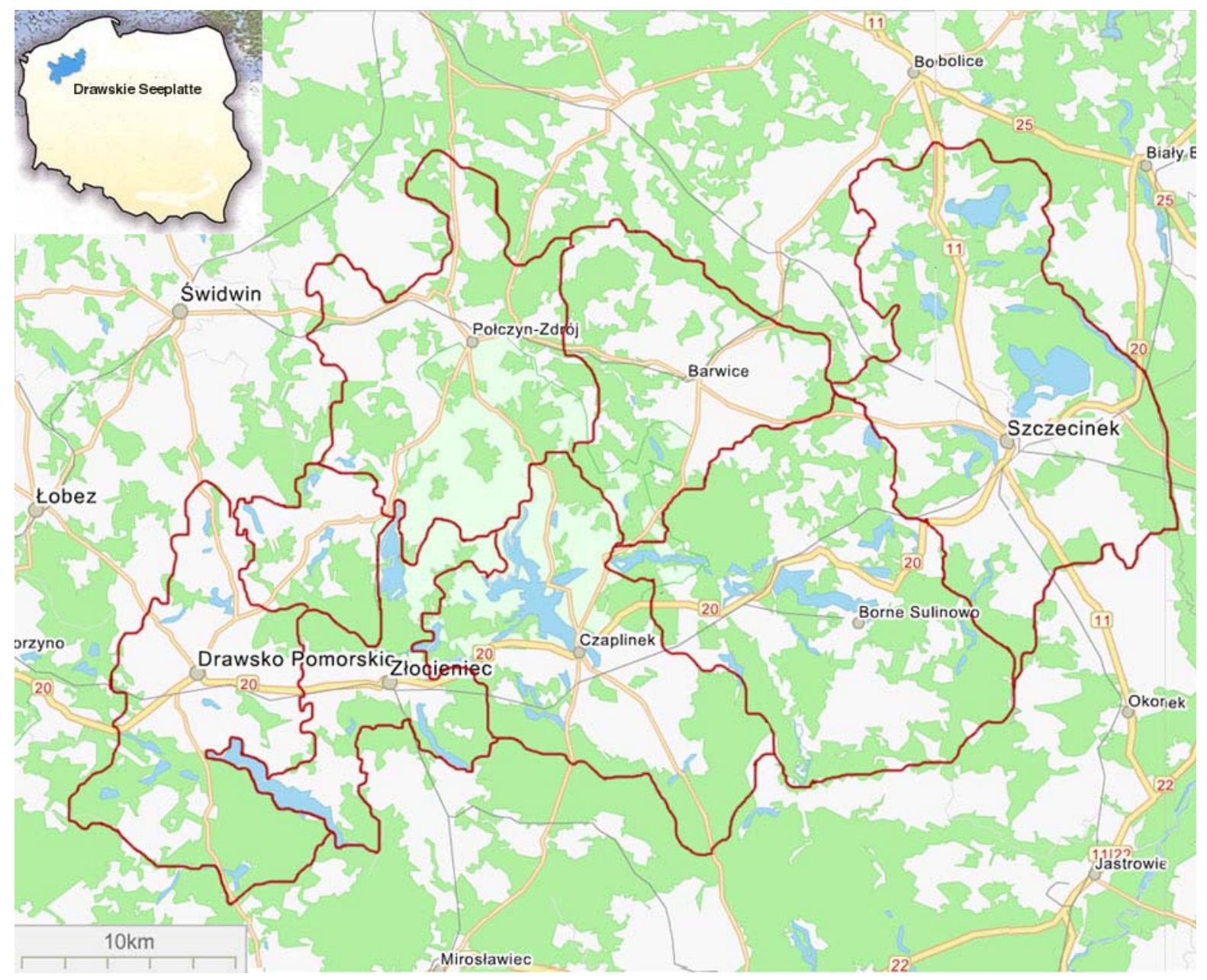

Fig 1. Case study area: the Drawskie Lake District

The most important industrial sectors are timber and construction industry ${ }^{8}$. The local authorities are forced to look for alternative sources of income for the local economy. Considering the high natural potential and the already recognised tourism potential, many municipalities (i.e. the principal units of territorial division with the competence to stimulate local economic development) indicate tourism as an important chance and a principal trend in the development strategy for this rural area.

The study region comprises $2000 \mathrm{~km}^{2}$ of scenic postglacial moraine landscape with significant relief diversification (from $64 \mathrm{~m}$ to $223 \mathrm{~m}$ above sea level) and over 250 lakes with areas of over 1 ha. Among them, there are gully lakes such as the biggest Drawsko Lake (1871 ha, $83 \mathrm{~m}$ deep) with considerable depths and well developed shorelines, islands. Other identified types are large, shallow lakes of the ground moraine located in deep valleys as well as meltdown lakes. The area is of great importance for nature conservation due to its natural rare habitats such as raised bogs and mires and fens, riparian forests, oligotrophic lakes with lobelia-species as well as a great diversity of vascular plants (750 species) and more than 274 moss species. The water bodies of the region were recognised as a core area of international significance, especially for the whitefish population. Because of the wealth of small and bigger water bodies, the District is a valued site for amphibians and avifauna (over 148 breeding bird species) (Liro 1995).

In the Drawski Lake District, the Park and numerous strict nature reserves were created from 1970s till 1990s in order to protect the landscape, flora and fauna. The park as well as some nature reserves is open to visitors, but nature conservation is its main objective and has priority over all other activities. Landscape park is a type of protected area of lower status than a national park and with less stringent restrictions on development and economic use. One of its purposes except the

\footnotetext{
${ }^{8}$ Rocznik statystyczny. Warszawa: Glówny urzad statystyczny
} 
conservation of natural, historical, cultural and scenic values is the recreation function. Additionally, three protected landscape areas were designated. The significance of the contribution of the area to the European natural heritage was recognised by the designation of the Czaplineckie Lakes, Lubie Lake and Drawa Valley and Drawska Ostoja as Natura 2000 areas. Natura 2000 area is an additional category, which may covered an area protected already as one or many of the forms mentioned above.

The attractiveness of the region has also been recognised by tourists, who have been visiting the District from the beginning of the $20^{\text {th }}$ century. With its numerous lakes and rivers, the region also provides attractions for water-based recreation, and lakeside holidays are the most popular form of tourism. The tourist survey of 2002 (Gołembski 2002) indicates the most popular tourist activities in the region: swimming (64\%) and angling (29\%). The $500 \mathrm{~km}$ of kayak routes are famous all over the country. Numerous designated hiking and cycling routes in this highly varied landscape are an additional tourist attraction. Finally, for $57 \%$ of the tourists, resting in an unspoilt, peaceful countryside is their main motivation to choose this holiday destination. Besides the natural scenic spots, architectural and historical monuments, historical parks as well as local culture (handicraft, artists) could be considered as potential tourist attractions; they are not promoted sufficiently. There is no data on the number of visitors in the studied area. According to Central Statistical Office of Poland ${ }^{9}$, the number of overnight guests is at 25,151 per year, with a rising tendency. In 2005, there were 136,977 overnight stays. The stock of accommodation amounts to 3,743 beds in 35 places of accommodation. In 2005, one of the most tourist-frequented municipalities Czaplinek estimated the number of its overnights guests at 18,000 persons during the summer season (from June until September) and offered 2,300 beds with an utilisation rate of $100 \%$ during the season. The steady growth of accommodation establishments is best to observe in Borne Sulinowo municipality (table 1).

\begin{tabular}{lllllllll}
\hline Type of facilities & Year & \multicolumn{10}{c}{} & & & & & & & \\
\cline { 2 - 8 } & $\mathbf{1 9 9 9}$ & $\mathbf{2 0 0 0}$ & $\mathbf{2 0 0 1}$ & $\mathbf{2 0 0 2}$ & $\mathbf{2 0 0 3}$ & $\mathbf{2 0 0 4}$ & $\mathbf{2 0 0 5}$ & $\mathbf{2 0 0 6}$ \\
\hline Agrotourism lodgings & 9 & 15 & 11 & 19 & 20 & 19 & 21 & 21 \\
Camping sites & 11 & 11 & 11 & 11 & 11 & 11 & 11 & 11 \\
Holiday centres & 6 & 6 & 6 & 9 & 9 & 9 & 10 & 10 \\
Other facilities & 10 & 13 & 11 & 6 & 6 & 7 & 8 & 11 \\
\hline Total & $\mathbf{3 6}$ & $\mathbf{4 5}$ & $\mathbf{3 9}$ & $\mathbf{4 5}$ & $\mathbf{4 6}$ & $\mathbf{4 6}$ & $\mathbf{5 0}$ & $\mathbf{5 3}$ \\
\hline
\end{tabular}

Tab 1. Tourist accommodation establishments in Borne Sulinowo municipality in 1999-2006 (Department for the Promotion of Tourism, Borne Sulinowo 2006).

\section{Methods}

By analysing the negative and positive impacts of tourism on the nature conservation, this study investigates whether co-operation between the tourism industry and nature conservation could contribute to preserving a rural landscape with its biodiversity and support the regional development of this area. The investigation of the perception of the effects of tourism on nature conservation by local stakeholders will lead to a more comprehensive understanding of relationship with the local municipalities and communities providing guidance in management of natural resources as well as information for a more efficient distribution of EU financial support.

The background study comprised of the analysis of documents related to the local strategies, the Drawski Landscape Park plans, and inventories of existing and proposed protected areas.

In order to collect information on perception of environmental change caused by tourism, 22 expert interviews were carried out during 2006. Expert interviews deliver useful background information and help to gain insight into the local situation. Using this method for the investigation of environmental impacts of tourism not only allowed to obtain information on the perception of such impacts but also to investigate their roots, the existing conflicts and cooperations, motivations, and social networks among the interviewees (Kassner and Wassermann 2002). Such data could not have been acquired in any other way, for instance by

\footnotetext{
${ }^{9}$ Rocznik statystyczny. Warszawa: Glówny urzad statystyczny
} 
survey questionnaires, which are a more common method in this field of research (Wong 2004). Additionally, through interviews with different stakeholders, a comparison of the topics and discrepancies assessed could be made (Leitner and Wroblewski 2002).

The experts were selected according to the definition by Meuser and Nagel (2005), which described them as individuals in charge of the draft, implementation and control of problems solution and therefore they have privileged access to the relevant knowledge. The representatives considered responsible for decision-making in the sectors of tourism and nature conservation were interviewed, e.g. members of tourist board, tourism promotion department, individual tourism enterprises, representatives of nature conservation such as the administration of the Park, environment departments of municipalities as well as other land users (administration of local forestry and fishery), and local politicians.

The face-to-face interviews, with their open, non-standardised form focused on two issues: the risk tourism poses to nature and the existing projects and co-operations between the tourism industry and nature conservation. The interviews were recorded and transcribed. The analysis of the interviews is based on a system of inductive and deductive categories.

\section{Results of the transformation process in rural landscapes}

The main change stressed by experts from the Drawski Landscape Park administration, tourism enterprises, the tourist board, municipalities and fisheries is the disturbance of the landscape caused by parcelling the land and by spontaneous, massive construction of summer houses, particularly on the lakeshore, their inappropriate architecture and the lack of matching architectural style. This affects practically the entire lakeshores, except those parts covered by forest; the rest of the lakefront has lost its original function mostly as agricultural land. The private construction activities destroy the shoreline by deforming the cliffs and removing the riparian vegetation and by setting up fences that reach into the lake. All these activities constitute a violation of the Polish Water Law Act ${ }^{10}$ and Nature Conservation Law ${ }^{11}$. However, from the point of view of the local authorities these violations are problematic to prove and it is difficult to enforce the regulation. As a result of architectural freedom and lack of regulations one can find typical mountain houses, half-timbered houses, and multi-storey summerhouses next to each other.

The representatives of the Park and local planners see the causes of these violations and negative developments in the lack of a coherent local land management plan and architectural regulations. The Polish Conservation Law does not include any legal instruments to preserve the scenic landscape with respect to its architectural form, even if these areas are protected by their status as a landscape park and a protected landscape area. The absence of a long-term land management policy of the local municipalities, which could have allowed them to secure attractive land or to forbid uncontrolled sales and conversion of agricultural land, is strongly criticised by all experts.

\section{Negative impacts of tourism on the natural environment}

The recognised risks to nature and their causes interpreted by the author as a result of tourism are shown in figure 2 .

In the view of the Drawski Landscape Park administration, phenomena such as illegal beaches, picnic spots, and fireplaces as well as the mass construction of jetties for anglers start to pose a serious problem to the environment with the increasing mobility of the local population and the intensified penetration by local people and tourists of the area. The interviewees representing the tourism sector and the local municipalities were not able to expressly indicate any conflict zones due to excessive pressure from the increased number of visitors.

\footnotetext{
${ }_{11}^{10}$ Dz. U. z 2005 r. Nr 239, poz. 2019. Ustawa z dnia 18 lipca 2005 roku Prawo wodne

${ }^{11}$ Dz.U. z 2004 r. Nr 92, poz. 880. Ustawa z dnia 16 kweitnia 2004 roku o ochronie przyrody.
} 


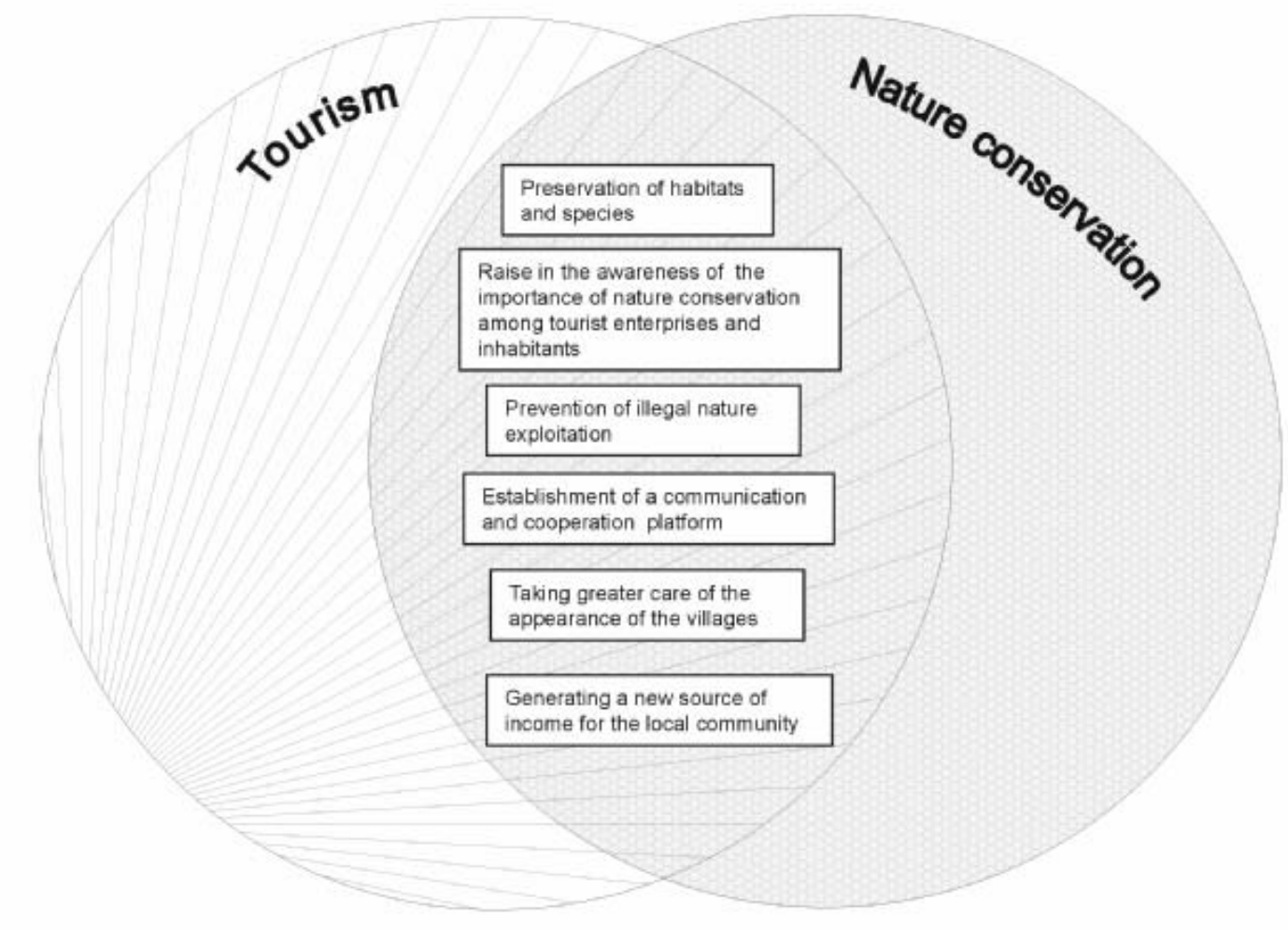

Fig 2. Risks to the nature and landscape and their root causes as recognised by experts

They stressed that tourism was not as developed as in other destinations located on lakes such as the Masurian Lake. Tour operators pointed out the problem of waste contamination and illegal toilets in the forest along the shoreline as a result of the insufficient infrastructure for the kayak tours on Drawa River, the most popular and frequented kayak route in the region. The local fishery administration of Siecino Lake was concerned of reaching the carrying capacity as the previously estimated limits for the number of lake users may already be exceeded. Because of the lack of data on visitor numbers it is not possible to make any clear statements. The potential risk resulting from uncontrolled recreation and tourism development on the Drawa River, Siecino Lake and Lubie Lake was emphasised during the inventory for the Natura 2000 area $^{12}$. In most of the municipalities, the lack of tourist data and information on the economic significance of tourism for the Drawskie Lake District are given as examples of the failure to develop tourism professionally.

With respect to the Park, there is a general fear of an increasing visitors demand. As mentioned by some tourist board representatives, the recent increase in the number of visitors, especially in the last 3-4 years, has raised the interest of investors in land for new resorts. The investors are not interested in modernising old resorts and renting land that is designated for recreation but prefer to buy new land, often very valuable natural sites. This process is considered as a clear indication of a prospering tourism in the region. In the opinion of the tourist boards, there will be no need to control the process and implement measures until the environmental carrying capacity is exceeded. However, as the local planners argue, the objectives of the development strategies change with every turn of local government and accelerate land consumption. In fact, any investor who wants to settle there and create jobs is accepted, even if compliance with sustainable development and the conservation of the area's natural potential is not always guaranteed.

Representatives of local tourism enterprises accused the local governments of a lack of clearly formulated development strategies for the region. In official documents, tourism based on

\footnotetext{
12 Waloryzacja przyrodnicza gminy Złocieniec, Biuro Konserwacji Przyrody w Szczecinie. Operat Generalny, unpublished, internal documents
} 
the area's high natural potential has been declared a very important factor for the development of each of the investigated municipalities.

According to some tourist enterprises and local tourist boards, the Park is used to demonstrate the high quality of the landscape and thus to promote tourism in the whole area. They expected the Park administration to show more commitment, open-mindedness, and co-operation in order to increase the knowledge about this valuable landscape among their guests and raise the awareness of the value of nature in the local population as well.

\section{Positive impacts of tourism on the natural environment}

Despite the negative impacts and all the problems in the Drawskie Lake District described above, representatives of the tourist boards emphasise many positive and innovative approaches with the aim to preserve the landscape as a tourist attraction.

Interviewees from the tourism enterprises named the establishment of silent zones, which had been implemented on the recommendation of tourism stakeholders, as a positive impact of tourism, which shows the common interest of tourism and nature conservation. Since 1999, after the administrative borders had been changed, lakes in the Drawski Landscape Park were no longer protected from noise and pollution coming from motorboats. In order to meet the needs of the visitors, and as a result of their complaints about being disturbed during their holidays, tourism enterprises achieved the introduction of silent zones. First they were introduced on Siecino Lake. In the summer season of 2006, the administration of the Park introduced them everywhere: motorboats were prohibited. Motorboat activities could still be carried out in the surrounding area.

\section{Local co-operation between the tourism and nature conservation}

The Borne Sulinowo tourist board stressed that the local societies and NGOs support many initiatives. The local tourist entrepreneurs and kayak fans around one of the rivers Pilawa and Drawa suited for kayaking founded a society for tourist management and the of the natural character of the river in order to ensure its status as a tourist attraction and a source of income. Tourism is considered an ally in preserving the area by preventing environment-damaging investments such as intensive livestock farming and also because it leads to the local people taking great care of the appearance and tidiness of the villages. In many tourist villages it is common practice to improve, maintain and brighten up the place. Several village revitalisation projects have already been started. Taking greater care of the village appearance and surrounding influences positively the landscape as well (figure 2).

Another initiative, which was started by the citizens of a small village community and received financial support from the Rural Development Foundation because of its innovative character, was called From Poacher to Guide. It focused on mobilising the rural community with respect to the utilisation of one of the lakes of Stawno and the prevention of poaching. Fishing without required permission is considered as a poaching and had become a serious problem, especially in poor villages with a high unemployment rate. In 2003, a commercial fishing ground with predatory fish was established in co-operation with the regional fishery. This campaign was preceded by water analysis and fauna inventory of the lake. Three villagers, former poachers, were responsible for the lake's cultivation and protection. The angling fees and service costs collected from the rising number of visitors created an additional income for the local community. The local inhabitants were allowed to fish legally after passing an angling exam for a very low fee. For the future, it is planned to establish a rental store for boats and angling equipment and a smokehouse as well as some paths for carts. In the framework of this project three new jobs for angling guides were created. This project has improved the natural condition of the lake's ecosystem and the regulation of the water regime, which had been destroyed by melioration.

One of the aims to preserve the landscape as a tourist attraction is to maintain almost 1600 ha of heathland in a former soviet military training area as a unique landscape and natural heritage. The heathland also supplies more than 80 beekeepers with honey plants and constitutes 
a basis for the regional product Drahim Honey. This product is only one part of the programme Drahim Area - a complex package of projects for the Drawskie Lake District. The idea was to promote the cultural and historical heritage of the District and strengthen the local identity. The programme was initiated by a few local stakeholders in co-operation with the society of development in the West Pomeranian Region Szczecin EXPO. It was created within the scope of a contest organised by some of the ministries under the title The Polish Region in the European Cultural Space in order to estimate the preparedness of the Polish regions to obtain EU support. In addition to the production of honey, the Drahim Market is organised every autumn to promote this honey, nature and a healthy lifestyle. The 'Trip for the Golden Fleece' is an educational offer addressed to schoolchildren from Szczecin, who participate in Green School and travel through this area, stopping in the heathland to learn about honey production and the beekeepers' profession and to experience Pomeranian rural areas. The main goal of the Drahim Area project was to preserve the heathland landscape, taking the area under conservation as a phytosociological reserve. The local forestry service maintains the land and is preparing a management plan. In order to preserve the landscape, the heathland will be mowed and its products will be sold as roof thatching material. The picturesque landscape is already the highlight of this area, attracting visitors to hiking and cycling trips, nature watching and for national open-air painting organised every year.

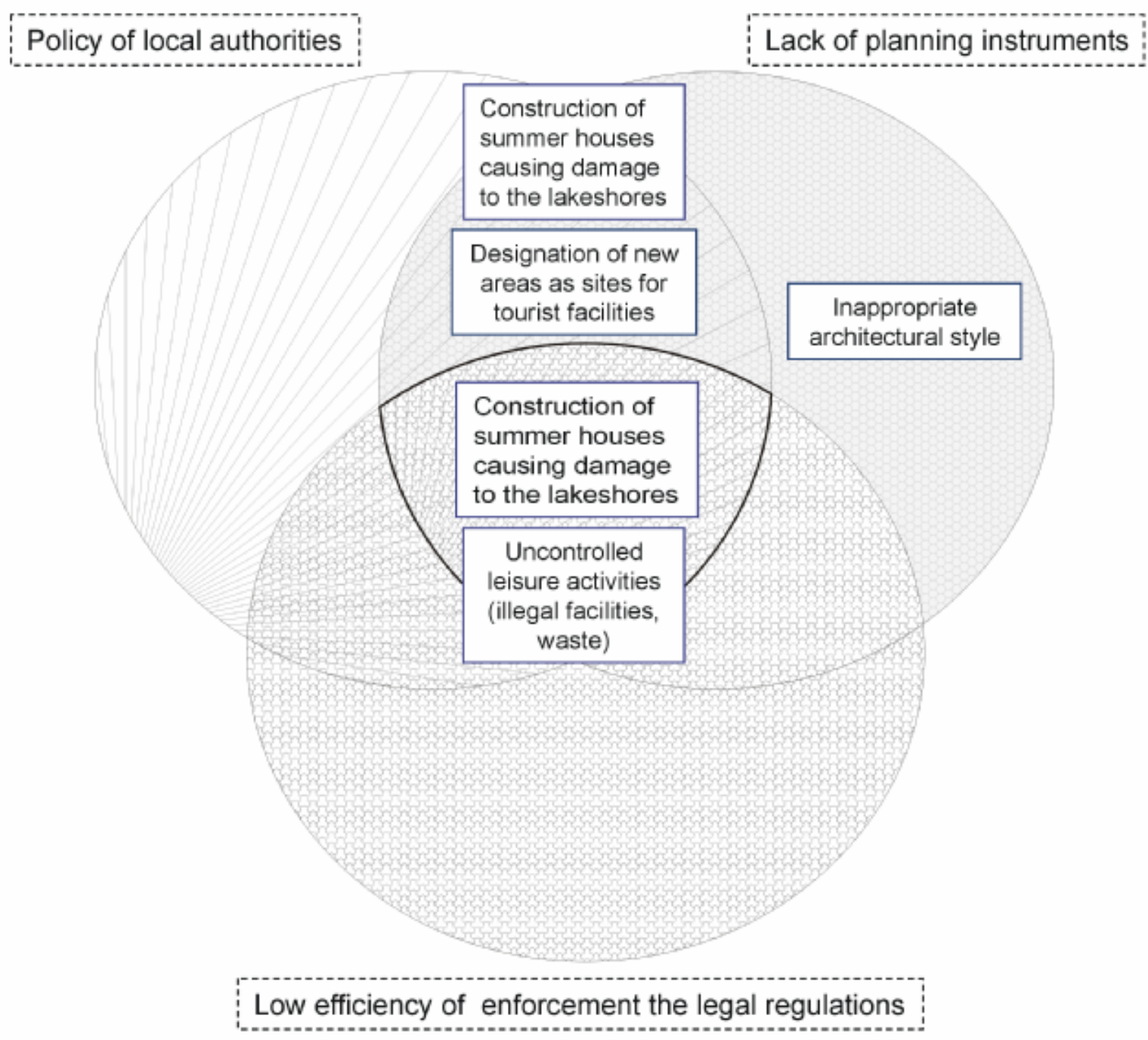

Fig 3. Synergies between tourism and nature conservation in the study area 


\section{Discussion}

The figure 2 shows that most of the negative impacts result from the lack of up-to-date planning and land management instruments on the local and regional level as well as the absence of appropriate local policy. The political implementation of the existing legislation is indicated as the third root cause. With the introduction of the new Spatial Management Act in Poland in 2003, the physical plans made before 1995 have expired. As a result, most of the voivodships in Poland and six of the seven municipalities investigated have no current local physical development plan covering their entire area (Kistowski 2003). In the absence of a local physical development plan, the decisions concerning the development conditions are made by the mayor. Consequently, the complex space is fragmented into a lot of very small, uncoordinated planning units. Decision-making is not supported by any deeper analyses: instead, the interests of investors who finance the preparation of detailed plans for small units, are taken into account (Chmielewski 2001).

This non-existence of coherent planning instruments, combined with the short-term policy of the authorities, which have no overall development concept, leads to the loss of many areas that have a high value for the nature conservation and are attractive to tourism - pointed out by experts as well as literature (Chmielewski 2001, Kistowski 2004). The rapid transformation process, together with the need to comply with EU laws, has caused many legal gaps and a lack of legal regulations (Iwaniuk 2000). Additionally, the decentralisation of power and responsibility did not provide any adequate support in terms of financial provision or competent staff (Hall 2000b).

Another problem that was mentioned are insufficient law enforcement efforts of the local governments and municipalities, for instance the Polish Water Law or Nature Conservation Law in the case of illegal construction, destruction of the shoreline or activities such as extending the fence around the property into the water.

One explanation could be the complexity of this problem and the necessity of a close cooperation on an institutional level between fisheries, the Drawski Landscape Park, departments of environment protection and local guards; another matter is the low willingness and insufficient law enforcement efforts of the incompetent authorities (Hall 2000b).

The results of the expert interviews show that most of the interviewees do not consider the recreational use of the lakes by the local population or the construction of summerhouses as risks to nature caused by tourism. For them 'tourism' is the industry sector aimed at receiving foreign visitors, including all the services they are offered. Furthermore, they are not aware of the many risks, which the development of both kinds of tourism may bear, such as rapid land consumption, which the experts from the tourism industry and the municipalities considered as a positive effect. This fact as well as the occurrence of the destruction of the shoreline, architectural chaos, and poaching express the poor knowledge of environmental ecology, landscape aesthetics, and the nature potential on the side of the stakeholders and inhabitants. This observation confirmed the results of the study by Burg (2000), which found insufficient environmental knowledge and willingness to conserve nature by Polish society. On the other hand, the positive examples presented above indicate the rising awareness of local tourist enterprises, which realise that only by preserving the landscape and nature they can ensure their source of income in the long term. The already existing co-operations show the interest in preserving the nature potential as a source of tourist attraction and income for the locals (figure 3). As Goodwin (1996) argues, the local people and the industry need to learn to appreciate the economic value of the protected as a tourist destination so that nature-based tourism can benefit from conservation. The presence of visitors and the media during promotional festivities will increase the local community's awareness of the high value of their home area. As the number of tourists is increasing, the Drawskie Lake District needs careful planning.

Currently, it can be driven in a sustainable direction much more easily. However, tourism can develop relatively spontaneously without any significant constraints. Even if at present there are no evident signs of the great numbers of visitors, the lack of appropriate management plans, policies, and action to prepare for any economic growth is recognised as a potential cause of considerable environmental damage (Gunn 1994). For this reason, an integrated land 
management plan putting particular emphasis on attractive locations with regard to natural areas and tourism is a fundamental requirement. Enforcement measures to ensure that development and tourism management are in agreement with ecological resources and potential are required. The primary aim of the land management plan is to establish the proper maintenance and designation of places for tourist and leisure functions, especially at the lakeshore. Strengthening nature conservation in land use planning by introducing landscape planning into the Polish system of land use planning and a continuous monitoring system for the nature inventory of the entire area is postulated by many landscape researchers (Dubel 2000, Kistowski 2003). If such data would be collected and supplied to the municipality, they could base their planning decisions on them. The updated information will allow a precise estimate of the ecological carrying capacity, which is defined as the saturation point that an ecosystem is able to bear without suffering irreparable damage (Mieczkowski 1995). Matuszewska (2003) considers the lack of empirical results on the carrying capacity of the natural environment and the lodging capacity in those areas as a main restriction for tourism development in protected areas.

Only by following the postulated co-operative and participative approach in the planning process, involving all land users and local inhabitants, an integrated land use management plan can be developed successfully. Also, a planning strategy, including tourism, has to be developed and accepted in co-operation with the local community; then it will have a chance to be actively supported and respected by them (Eagles et al. 2002, European Commission ${ }^{13}$, Hall 2000a, Goodwin 1996, Wight 1998, WTO ${ }^{14}$ ). This is also the subsidiary principle of the regional EU policy. The implementation of regulations on architectural styles, especially in the landscape parks, is necessary for preserving the conservation and economic value and the quality of the rural landscape for the tourism and locals. According to a study carried out by Ryszkowski and Karg (2001) in 50\% of the Polish landscape parks, the construction and architecture of unauthorised houses was considered as negative human pressure on the environment in $31 \%$ of the cases.

Joint activities to prevent poaching, especially on lakes, are not only important from the ecological point of view but also to ensure the livelihood of local fisheries, which are losing their market due to the poaching.

The main task of the board of the Drawski Landscape Park as the main authority responsible for nature conservation in the region is the promotion of the high value of the area among local inhabitants and tourists. The administrations of many protected areas feel that the protection of nature is a higher-ranking task than the targets of the local community, which is a source of conflict (Matuszewska 2003, Zimniewicz 2005). For conservation schemes to be effective, the co-operation of all the parties involved is necessary. The existence of the Park as well as many other forms of protected areas, especially Natura 2000, provides good conditions for ecotourism. With respect to this fact, the Park has to become a coordinator of the development of the tourism function and to establish a close co-operation with the local tourist boards and enterprises. The European Charter for Sustainable Tourism, a strategic instrument required by the EU in agreement with the International Union for Nature Conservation (IUCN) and managed by the EUROPARC Federation ${ }^{15}$ (2007), provides the necessary guidelines. The Charter aims to promote sustainable tourism in protected areas. It requests the Park managers and tourism operators to create networks working out common strategies and an action plan to develop sustainable tourism. Due to interesting cultural assets (historical ruins, local handicraft and artists, festivities) and a growing interest in spending holidays in agritourism ${ }^{16}$ accommodation, the ecotourism market can be based upon nature in combination with cultural attractions. In this

\footnotetext{
13 A Renewed EU Tourism Policy: Towards a Stronger Partnership for European Tourism http://ec.europa.eu/enterprise/services/tourism/commission_communication/doc/tourism_communication_en.pdf _ 5.12.2006.

${ }_{14}$ WTO $(1994)=$ World Tourism Organisation. National and Regional Tourism Planning. Methodologies and Case Studies. London: Routledge, pp. 450-462.

${ }_{15}^{15}$ Europarc (2007). http://www.europarc.org/european-charter.org/index.html - 8.04.2007.

16 The concept of agritourism is a direct expansion of ecotourism (Scace 1993), which encourages visitors to experience agricultural life at first hand.
} 
way, the flow of tourists can be directed away from sensitive areas. On the other hand, the District has always been a water-based tourist destination and this form of tourism should be managed very carefully to minimise its negative impacts. Because of its multisectoral character any successful collaboration between the tourism industry and nature conservation requires steady communication between the parties involved and also the establishment of a co-operation platform for the different institutions and municipality members. Taking all these factors into account, it may be assumed that the relation between tourism and nature conservation may develop towards achieving synergies if the mentioned conditions are considered.

\section{Conclusions}

The presented problems and impacts on nature are common not only in the region of the Drawski Lake District but also in many other rural regions in Central and Eastern Europe, which experienced an enormous transformation in a very short time with respect to political, economic and particularly social changes. As the study of the District shows, the awareness of the value of nature and the importance of it is increasing among the local inhabitants because they realise that it has great tourism potential and therefore is an important source of income. The fact that the tourism in the District does not show any excessive pressure yet and does not appear as a mass tourism makes it easier to strive for sustainability. However, in order to assist the longer-term sustainability of tourism and make a contribution to the natural potential there, strong commitment of local authorities is needed. In the new member states, EU support for the development of tourism can only achieve the desired sustainability if the municipal and regional levels are provided with the necessary management instruments and legal regulations. They also need to ensure that the rules of civil society such as co-operative and participative approach are implemented effectively and reliably.

\section{Acknowledgements}

The author gratefully acknowledges the assistance received by supervisors Prof. Dr. Renate Bürger-Arndt and Prof. Ulrich Harteisen as well as two anonymous reviewers.

This paper is based on a project entitled Drawskie Lake District funded by the University of Applied Sciences and Arts Hildesheim/Holzminden/Göttingen (ESF).

References

[1] Bański, J. (2002). Land management in Poland in the period of transformation. In: Helming, K. \& H. Wiggering (eds.) Sustainable Development of Multifunctional Landscape (pp. 217227). Berlin: Springer.

[2] Baranowska-Janota, M. (1995). Ku ekoturystyce w polskich parkach narodowych. Parki Narodowe i Rezerwaty Przyrody 14 (4): 119-128.

[3] Budowski, G. (1976). Tourism and environmental conservation: conflict, coexistence, or symbiosis? Environmental Conservation 3(1), 27-32. Doi:10.1017/S0376892900017707.

[4] Burg, T. (2000). Świadomość ekologiczna społeczenstwa polskiego u progu XXI wieku. Raport 1. Warszawa: Instytut na Rzecz Ekorozwoju.

[5] Burger, J. (2000). Landscape, tourism and conservation. The Science of the Total Environment 249(1-3): 39-49. Doi:10.1016/S0048-9697(99)00509-4.

[6] Chmielewski, T.J. (2001). System planowania przestrzennego harmonizującego przyrodę i gospodarke. Tom 1, 2. Lublin: Politechnika Lubelska.

[7] Dubel, K. (2000). Uwarunkowania przyrodnicze w planowaniu przestrzennym. Białystok: Wydawnictwo Ekonomia i Środowisko. 
[8] Eagles, P.F.J., F. McCool \& C.D. Haynes (eds.) (2002). Sustainable tourism in protected areas. Guidelines for planning and management. Best Practice Protected Area Guidelines Series 8. Gland: IUCN Publication.

[9] Frenkel, I. (1997). Ludność, zatrudnienie i bezrobocie na wsi. Dekada przemian. Warszawa: IRWiR, PAN.

[10] Gołembski, G. (2002). Metody stymulowania rozwoju turystyki w ujeciu przestrzennym. Poznań: Wydawnictwo Akademii Ekonomicznej w Poznaniu.

[11] Goodwin, H. (1996). In pursuit of ecotourism. Biodiversity and Conservation 5(3): 277-291. Doi: $10.1007 / B F 00051774$.

[12] Gunn, C.A. (1994). Tourism Planning: Basics, Concepts, Cases. Washington: Taylor \& Francis.

[13] Hall, D.R. (2000a). Evaluating the tourism-environment relationship: Central and Eastern European experiences. Environment and Planning B: Planning and Design 27 (3): 411-421. DOI: $10.1068 / \mathrm{b} 2661$.

[14] Hall, D.R. (2000b). Sustainable tourism development and transformation in Central and Eastern Europe. Journal of Sustainable Tourism 8(6): 441-457. Doi: 10.1080/09669580008667379.

[15] Iwaniuk, K. (2000). Zgodność i działania dostosowawcze polskiego prawa do wymogów Unii Europejskiej w zakresie ochrony przyrody. In: Sasinowski, H. (Ed.) Ekorozwój w polityce regionalnej: ekonomiczne aspekty ekorozwoju, Tom 1 (pp. 143-61). Białystok: Politechnika Białostocka,.

[16] Jagusiewicz, A. (2000) Gospodarka turystyczna na przyrodniczych obszarach chronionych. Rynek Turystyczny 13-14: 9-11.

[17] Kassener, K. \& Wassermann P. (2002). Nicht überall, wo Methode draufsteht, ist auch Methode drin. Zur Problematik der Fundierung von ExpertInneninterviews. In: Bogner, A., Littig, B. \& Menz, W. (Eds.), Das Experteninterview. Theorie, Methode, Anwendung (pp. 95111). Opladen: Leske + Budrich.

[18] Kistowski, M. (2003). Does Polish system of physical planning ensure effective nature conservation? Przegląd przyrodniczy 14 (3-4): 19-40.

[19] Kistowski, M. (2004). Wybrane aspekty zarządzania ochroną przyrody w parkach krajobrazowych. Poznań: Bogucki Wydawnictwo Naukowe.

[20] Kowalczyk, A. (1996). Sustainable development and perspectives for development of tourism in rural areas in Poland. Miscellanea Geographica 7: 197-201.

[21] Leitner, A. \& Wroblewski, A. (2002). Zwischen Wissenschaftlichkeitsstandard und Effizienzansprüchen. Experteninterviews in der Praxis der Arbeitsmarktevaluation. In:

[22] Liro, A. (1995). Koncepcja krajowej sieci ekologicznej ECONET-POLSKA. Warszawa: IUCN.

[23] Matuszewska, D. (2003). Funkcje turystyczne i konflikty w wybranych parkach narodowych Polski północno- zachodniej. Poznań: Bogucki Wydawnictwo Naukowe.

[24] Meuser, M. \& Nagel, U. (2005). Vom Nutzen der Expertise. ExpertInneninterviews in der Sozialberichterstattung. Bogner, A., Littig, B. \& Menz, W. (Eds.), Das Experteninterview. Theorie, Methode, Anwendung (pp. 257-272). Opladen: Leske + Budrich.

[25] Mieczkowski, Z. (1995). Environmental Issues of Tourism and Recreation. Lanham: University Press of America.

[26] Nowaczek, A.M. \& Fennel, D.A. (2002). Ecotourism in post-communist Poland: an examination of tourist, sustainability and institutions. Tourism Geographies 4 (4): 372395. DOI: $10.1080 / 14616680210158137$. 
[27] Poskrobko, B. (2005). Zarządzanie turystyką na obszarach przyrodniczo cennych. Białystok: Wydawnictwo Białystok.

[28] Ross, S. \& Wall, G. (1999). Ecotourism: toward congruence between theory and practice. Tourism Management 20: 123-132. Doi:10.1016/S0261-5177(98)00098-3.

[29] Ryszkowski, L. \& Karga, J. (2001). Przeciwdziałanie zagrożeniom środowiska i ochrona przyrody w parkach krajobrazowych. In: Ryszkowski, L. \& Bałazy, S. (Eds.), Ochrona parków krajobrazowych a działalność gospodarcza (pp. 40-58). Poznań: Zakład Badań Środowiska Rolniczego i Leśnego.

[30] Scace, R. (1993). An ecotourism perspective. In Nelson, J., Butler, R., and Wall, G. (Eds.), Tourism and Sustainable Development: Monitoring, Planning and Managing (pp. 59-81), Department of Geography, University of Waterloo, Ontario.

[31] Wight, P. (1998). Tools for sustainability analysis in planning and managing tourism and recreation in the destination. In: Hall, C.M. \& Lew A.A. (Eds.), Sustainable Tourism: A Geographical Perspective (pp. 75-92). New York: Longman,

[32] Wong, P.P. (2004). Environmental impacts of tourism. In: Lew, A.A., Hall C.M. \& Williams, A.M. (Eds.), A Companion to Tourism. Oxford: Blackwell Publishing.

[33] Zaręba, D. (2006). Ekoturystyka: wyzwania i nadzieje. Warszawa: PWN.

[34] Zimniewicz, K. (2005). Zarządzanie parkiem krajobrazowym w warunkach zrownóważonego rozwoju. Poznań: Akademia Ekonomiczna w Poznaniu. 